\title{
The Etruscan Banquet: the Dream of Many, the Reality of Few. Nutritional Framework of Human Etruscan Groups in Volterra
}

\author{
A. Bacci ${ }^{1}$, A. Franceschi ${ }^{1}$, F. Bartoli ${ }^{1}$, F. Mallegni ${ }^{1}$ \\ 1Departmentof Biology, University of Pisa. E-mail: fbartoli@biologia.unipi.it
}

KEYWORDS: incinerated, paleodiet, trace elements, Etruscans.

\section{Introduction}

The main objective of this research is to define the dietary habits of different groups of people lived in the Etruscan town of Volterra and evaluate any changes in the course of two different chronological phases: the phase of Villanova (IX-VII century BC) and Hellenistic period (III-II century BC). It also aims to verify the existence of a possible relationship between the traditional image of eating habits, which is celebrated by the Etruscan iconographic sources, and the data emerging from the analytical study of human skeletal remains.

\section{Materials and Methods}

The samples, analyzed by Atomic Absorption Spectroscopy (AAS), belong to the collection of Guarnacci Museum in Volterra, in which they identified two groups of Villanovian age and a third group of the Hellenistic period: a total of 36 cremated samples, of which only 25 are considered suitable for paleonutritional analysis. The exclusion from the analysis of some samples is due either to the absence of useful osteological districts within of the urn or to a clear contamination of the samples. For the reconstruction of eating habits of the Villanovian phase, we analyzed 16 samples from the necropolis of Le Ripaie (XIX - VIII century BC), where 21 burials, preserved in biconical urns with a bowl as lid, were found in simple earthen graves or in cylindrical pit tombs with drywall and tombstone (Cateni, 1981). The tipology of burials and of the pottery mixture of the biconical urns seems to refer to a cultural unit (Cateni, 2004).

For the immediately following chronological stage, we also examined 5 samples from the necropolis of Guerruccia (second half of the eighth century BC - early seventh century $\mathrm{BC}$ ), where burials - either inhumation either cremation - have been found of different type: in the simple pit, in crate or in jar, with the ashes preserved in typical biconical urns or in ceramic urns painted with ventricose forms (Mugnai, 1987).
Finally, the elaboration of the nutritional situation of the Hellenistic period is based on the study of four individuals preserved in the Pineschi tomb of the Portone's necropolis: a rectangular chamber tomb, which at the time of the discovery - by prof. Fiumi in 1970 - still had a lytic slab in situ as a closure of the dromos. Two urns of alabaster and three in tufo of Pignano were placed on the dock of deposition, as well as two unpainted craters, one of which shattered: seven burials within a few generations, for a chronological period between the end of the third and half of the second century BC (Cateni, 2004).

For all samples tested - both of the Villanovian age and of the Hellenistic period - the maximum temperatures of cremation are estimated between $550^{\circ} \mathrm{C}$ and 630 ${ }^{\circ} \mathrm{C}$ according to the correlation between color and temperature (Shipman, 1984). The macroscopic alteration of skeletal remains, which were cremated at rather high temperatures, is unable to make a diagnosis of sex and age at death accurate and valid (Romagnoli, 1997). It was further possible to insert the sample into broad groups of age: all the subjects examined proved to adults or young adults and have not identified the remains of infants or children. Finally, no evidence of pathological markers may be indicative of an effective and general well-being of human groups under study, but could be attributed to the fragmented nature of the material and the profound changes caused by the action of fire. These changes included the progressive combustion of the organic portion of the bone tissue up to $400^{\circ} \mathrm{C}$ and recrystallisation of the bone tissue beginning at $600^{\circ} \mathrm{C}$ (Holden et al., 1995). The main original structural features of the mineralized bone tissue were unaltered when the specimes were heat - treated at any temperature in the range $200^{\circ}-600^{\circ} \mathrm{C}$ (Holden et al., 1995).

Paleonutritional investigations, applied to the collection of cremated of the Guarnacci's Museum in Volterra, are processed by evaluating the concentrations of some trace elements, set in the bones through diet: strontium as an indicator of mostly vegetarian diet and zinc as an indicator of principally protein diet: particularly high concentrations of strontium are contained in green leafy vegetables, but also in molluscs and small fish (Sillen and Kavanagh, 1982; Brown, 1974), while significant levels of zinc (Underwood, 1977 ) are found in red meat, milk and dairy products, but also in molluscs and crustaceans of marine origin. The osteological samples, subject to appropriate and specific 


\begin{tabular}{|c|c|c|c|}
\hline 29 & $66 \mathrm{~L}$ & t0Z & In diy \\
\hline$\varepsilon 9$ & ยレレ & 902 & $\perp$ dly \\
\hline ルレ & $\angle 9 l$ & LOZ & IS dIY \\
\hline 69 & 6SL & SOZ & Odly \\
\hline 19 & OZL & $\varepsilon 0 Z$ & IN dIY \\
\hline$t 9$ & 86 & 812 & $17 \mathrm{~d}$ \\
\hline t9 & $L E L$ & 861 & 〔 diy \\
\hline$t t l$ & $\angle L L$ & 861 & LH dIY \\
\hline SOL & OZL & 802 & لע \\
\hline OLL & $\angle 6 L$ & $\varepsilon 0 乙$ & $\exists d I y$ \\
\hline OOL & SGL & 912 & $\exists$ dly \\
\hline$\varepsilon L$ & 9LL & SOZ & 1כ dIप \\
\hline$\nabla Z L$ & ZLL & 002 & כ ע \\
\hline SEL & $l \angle L$ & Z०२ & I $\forall$ dI \\
\hline $\begin{array}{l}\text { (usdd) } \\
\text { su!Z }\end{array}$ & $\begin{array}{c}\text { (wdd) } \\
\text { un!̨uod7s }\end{array}$ & $\begin{array}{c}\text { (8/8ిw) } \\
\text { un!כ|eכ }\end{array}$ & ר כ!ed!y \\
\hline
\end{tabular}

wadd u!

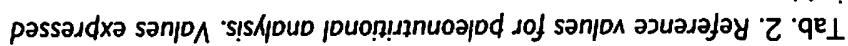

\begin{tabular}{|c|c|c|}
\hline 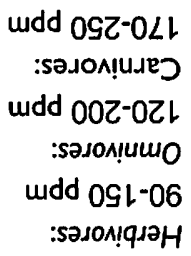 & 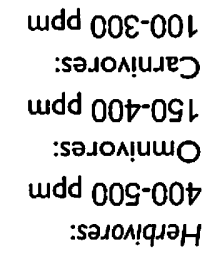 & క/ฉిm 0SE-0SZ \\
\hline su!z & un!zuod7s & un!̣गeว \\
\hline
\end{tabular}

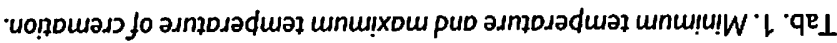

\begin{tabular}{|c|c|c|}
\hline ว. $0 \varepsilon 9$ & כ.00L & 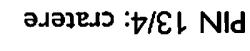 \\
\hline ว. $0 \varepsilon 9$ & ग.099 & t69: $t / \varepsilon L$ NId \\
\hline ว. 0\&9 & 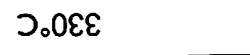 & $\varepsilon 69: \nabla / \varepsilon L$ Nid \\
\hline つ. $0 \varepsilon \varepsilon$ & 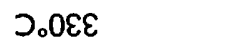 & Z69: †/EL NId \\
\hline $\begin{array}{l}\text { əגnjesəduə } \perp \\
\text { unu!XeW }\end{array}$ & $\begin{array}{l}\text { osnzesəduə } \perp \\
\text { unnu!u!W }\end{array}$ & !yગsou!d equol \\
\hline ว.0\&9 & ว.099 & 8 y \\
\hline ग.0S9 & ग.099 & 9 פח 9 \\
\hline כ.0SG & ग.099 & $\downarrow$ ๑ \\
\hline ว.0\&9 & J.0S9 & 乙 2 ป \\
\hline ग.0S9 & J.099 & פ \\
\hline $\begin{array}{l}\text { osnzesəduə } \perp \\
\text { unu!XeW }\end{array}$ & $\begin{array}{l}\text { әגnวедәduə। } \\
\text { unu!u!W }\end{array}$ & רן \\
\hline ว.0£9 & ગ.099 & עוd ^וררך \\
\hline 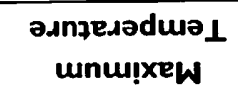 & $\begin{array}{l}\text { ә.лnұeגəduə| } \\
\text { unu!u!W }\end{array}$ & כ!̣ed!y әา \\
\hline
\end{tabular}

\begin{tabular}{|c|c|c|}
\hline つ.0દE & כ.00L & $\wedge$ dly \\
\hline ว.0\&9 & 2.001 & In diy \\
\hline 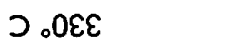 & 2.001 & $\perp$ dil \\
\hline つ. ০\&9 & ग.099 & IS dIV \\
\hline 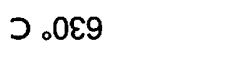 & כ.0SS & O diy \\
\hline כ.099 & J.0SS & IN diy \\
\hline ว.0\&9 & J.09S & 17 d \\
\hline כ.099 & J.0S9 & I diy \\
\hline כ.099 & ग.0S9 & LH dIt \\
\hline כ 。 $0 \varepsilon 9$ & ว.0६9 & لاd \\
\hline ว . ૦૯9 & ว.0\&9 & $\exists$ dIy \\
\hline כ.099 & J.0SS & $\exists$ dil \\
\hline 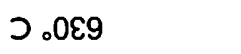 & ग.0SS & IJ diy \\
\hline 099 כ & ว.099 & ע כ כ \\
\hline כ.099 & J.099 & L $\forall$ dIy \\
\hline 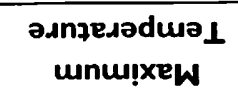 & $\begin{array}{l}\text { asnzesəduə] } \\
\text { unu!u!W }\end{array}$ & ə!ed!y ә \\
\hline
\end{tabular}

$\cdot$ (uo!n!ाu dad s7.jed)

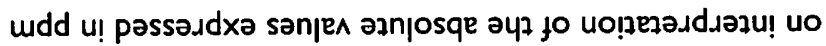

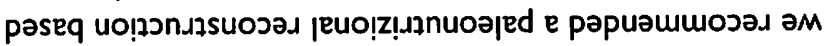

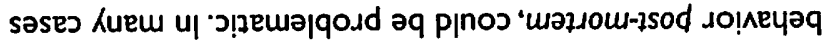

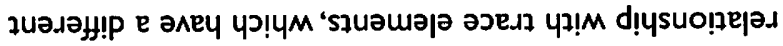

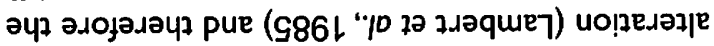

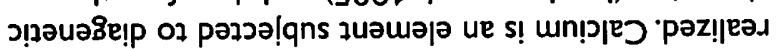

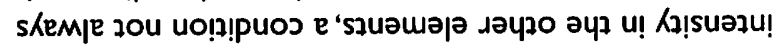

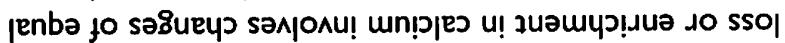

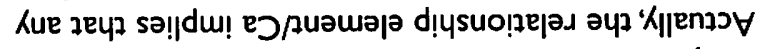

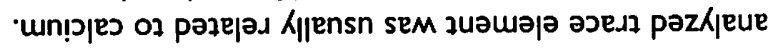

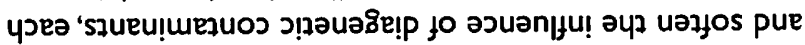
едер әцд әz!p

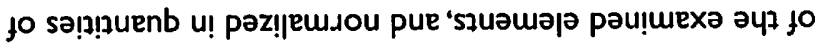

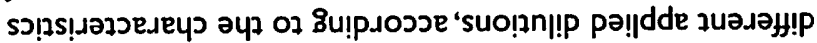

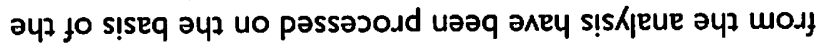

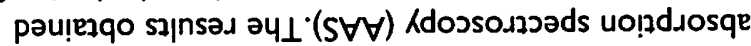

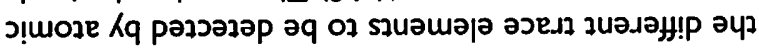

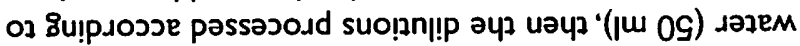
pə|ा!

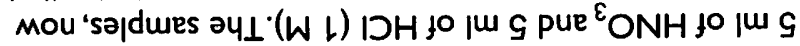

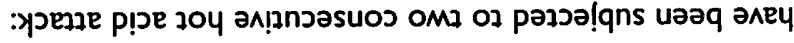

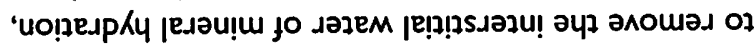

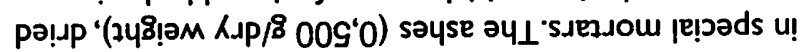

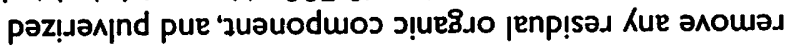

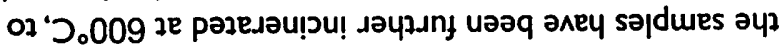

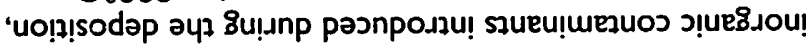

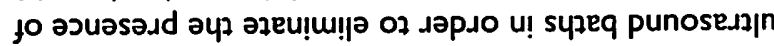

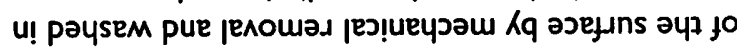

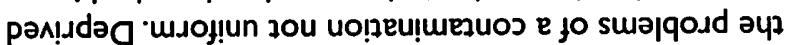

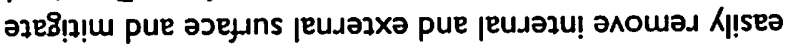

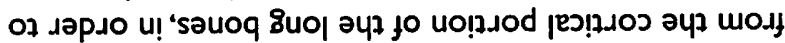

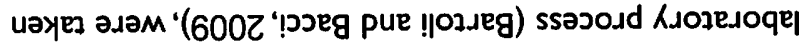


The Etruscan Banquet: the Dream of Many, the Reality of Few. Nutritional Framework of Human Etruscan Groups in Volterra

\begin{tabular}{|c|c|c|c|}
\hline Le Ripaie & $\begin{array}{c}\text { Calcium } \\
\text { (mg/g) }\end{array}$ & $\begin{array}{l}\text { Strontium } \\
\text { (ppm) }\end{array}$ & $\begin{array}{c}\text { Zinc } \\
(\mathrm{ppm})\end{array}$ \\
\hline RIP V & 206 & 154 & 53 \\
\hline RIP VILL.L & 203 & 221 & 58 \\
\hline La Guerruccia & $\begin{array}{l}\text { Calcium } \\
(\mathrm{mg} / \mathrm{g})\end{array}$ & $\begin{array}{l}\text { Strontium } \\
\text { (ppm) }\end{array}$ & $\begin{array}{c}\text { Zinc } \\
(\mathrm{ppm})\end{array}$ \\
\hline GUER 1 & 202 & 112 & 74 \\
\hline GUER 2 & 206 & 98 & 38 \\
\hline GUER 4 & 207 & 144 & 50 \\
\hline GUER 6 & 201 & 109 & 32 \\
\hline GUER 8 & 204 & 94 & 37 \\
\hline $\begin{array}{c}\text { Tomba } \\
\text { Pineschi }\end{array}$ & $\begin{array}{l}\text { Calcium } \\
\text { (mg/g) }\end{array}$ & $\begin{array}{l}\text { Strontium } \\
\text { (ppm) }\end{array}$ & $\underset{(\mathrm{ppm})}{\text { Zinc }}$ \\
\hline PIN 13/4: 692 & 197 & 211 & 160 \\
\hline PIN 13/4: 693 & 204 & 131 & 45 \\
\hline PIN 13/4: 694 & 198 & 325 & 197 \\
\hline $\begin{array}{l}\text { PIN 13/4: } \\
\text { cratere }\end{array}$ & 203 & 161 & 71 \\
\hline
\end{tabular}

Tab. 3. Paleonutrition onalysis results. Volues expressed in ppm.

\begin{tabular}{|l|r|r|}
\hline & \multicolumn{1}{|c|}{ Sr/Ca } & \multicolumn{1}{c|}{ Zn/Ca } \\
\hline Le Ripaie & $0,75 \pm 0,19$ & $0,43 \pm 0,12$ \\
\hline La Guerruccia & $0,54 \pm 0,09$ & $0,23 \pm 0,09$ \\
\hline Tomba Pineschi & $0,95 \pm 0,47$ & $0,59 \pm 0,37$ \\
\hline Standard & 0,71 & 0,67 \\
\hline
\end{tabular}

Tab. 4. Paleonutrition analysis results. Mean values expressed as ratio element/Co.

The osteological collection, being the result of ancient excavations, does not have specific reports of excavation to allow a clear contextualization of findings and does not have samples of fauna useful for the correction of the analytical data with the site, by comparing the concentration levels of the human samples with those of herbivores lived simultaneously in the same site.

\section{Results}

The analysis results show a consistent - but steady - depletion of calcium, with average values of $204 \pm 5 \mathrm{mg} / \mathrm{g}$, and a substantial uniformity of diagenetic behavior between the Villanovian period (IX-VII centuryBC) and the period Hellenistic (third -second century $B C$ ). The food situation on villanovian samples from the necropolis of Le Ripaie results to be uniformly characterized by vast amounts of vegetable at the expense of protein intakes. In the population represented

by this necropolis is possible to isolate a group - RIP C1, RIP G1, RIP J, RIP L1, RIP N1, RIP T - that shows modest, but constant, levels of strontium and zinc ( $\mathrm{Sr} / \mathrm{Ca}: 0,54$ $\pm 0,09$ e $\mathrm{Zn} / \mathrm{Ca}: 0,35 \pm 0,08)$ related to a nutritional framework consisting of very low intakes of vegetable and protein.

The remaining and larger sample has a nutritional framework of greater well being tilted in favor of vegetable and fish intake represented by very high concentrations of strontium ( $\mathrm{Sr} / \mathrm{Ca}: 0,87 \pm 0,11)$ and at the expense of protein intake $(\mathrm{Zn} / \mathrm{Ca}: 0,48 \pm 0,17)$ indicative of a small but systematic consumption of meat.

The analysis conducted on samples of the necropolis of Guerruccia show levels of concentration ( $\mathrm{Sr} / \mathrm{Ca}: 0,54 \pm$ 0,09 and $\mathrm{Zn} / \mathrm{Ca}: 0,23 \pm 0,09$ ) compatible with the modest food situation found in most poor human group, isolated in the necropolis of Le Ripaie.

The samples from the Hellenistic Pineschi Tomb reveal finally a different situation: two people (PIN 693 e PIN CR.) have a nutritional framework similar to that characterizing Villanovian groups - modest, but not too poor, essentially vegetarian - while the remaining two individuals (692 and PIN PIN 694) show a situation of extraordinary well-being, characterized by an excellent consumption of vegetables and a considerable intake of prutein and shellfish. The high variability of concentration levels of zinc and strontium ( $\mathrm{Sr}$ / Ca: $0.95 \pm 0.47$ and $\mathrm{Zn} / \mathrm{Ca}: 0.59 \pm 0.37$ ) seems to be the result of a major social differentiation and seems to indicate a nutritional framework in which stands out - for its rich dietary intakes - the individual PIN 694, associated with the main burial - the masculine urn - accompanied by an impressive set of ceramic dishes, forming the served by banquet.

\section{Discussion}

In the context of Villanovian phase, the nutritional framework is uniformly characterized by a clear preponderance of vegetable intake and a fair chance of access to food. The situations of more or less wellness - highlighted by our data - do not seem to be such as to justify significant social differentiation. The nutritional framework that emerges seems to be in line with the extreme simplicity of the economic and social components of this early Iron Age, in which the distribution of wealth must be uniform and subsistence strategies should be focused mainly on agriculture and exploitation of the environment.

The data relating to Hellenistic samples show a nutritional framework, where the variability of nutrient intakes seems to be index of a different accessibility to food resource, as a result of a major social differentiation. This nutritional framework can be compatible with the traditional image of the Etruscan banquet, in which the consumption of meat played an important role, as a sign of wealth of the nobility. In this sense, the data relating to these subjects seem to reflect the image of the rich banquet, celebrated in the ancient sources. 


\section{References}

Bartoli F., Bacci A. 2009. Regime alimentare nei gruppi umani del passato. In: Mallegni F., Lippi B., $n^{\circ} 9$, Non omnis moriar, CISU, Roma.

Bartoli F., Mallegni F., Fornaciari G. 1997. Le risorse alimentari nel mondo etrusco: aspetti della paleodieta in due gruppi umani a cultura etrusca. In:Atti del XIX Convegno di studi Etruschi ed Italici, Aspetti della cultura etrusca fra l'età del ferro e l'etò ellenistica e contributi dalla ricerca antropologica alla conoscenza del popolo etrusco, Leo S. Olschki Editore, Firenze.

Brown A. 1974. Bone strontium content as a dietary indicator in human skeletal populations. Rocky Mt Geology, 13/2: 47-48.

Cateni G. 1981. La necropoli villanoviana delle Ripaie a Volterra. In:A.A.V.V., Etruria Mineraria: 193-198.

Cateni G. 2004. Volterra, Museo Guarnacci. Pacini Editore, Pisa.
Holden J.L., Phakey P.P., Clement J.G. 1995, Scanning electron microscope observations of heat-treated human bone. Forensic Sci. Int, 74: 29-45.

Lambert J.B., Simpson S.V., Szpunar C. P., Buikstra J.E. 1985. Bone Diagenesis and Dietary Analysis.J. Hum. Evol., 14:477-482.

Mugnai M. 1987. Contributo alla definizione della sequenza villanoviana di Volterra: revisione degli scavi Ghirardini e Chierici alla Guerruccia. Thesis for degree, University of Siena.

Romagnoli M. 1997. I cremati nelle collezioni del Museo Guarnacci di Voiterra (PI). In:Atti del XIX Convegno di studi Etruschi ed Italici, Aspetti della cultura etrusca fra l'etò del ferro e l'età ellenistica e contributi dalla ricerca antropologica allo conoscenza del popolo etrusco, Leo S. Olschki Editore, Firenze.

Sillen A., Kavanagh M. 1982. Strontium and paleodietary research: a review. Yearb Phys. Anthropol., 25:67-90.

Underwood E.J. 1977. Trace elements in human and animal nutrition. Academic Press, New York. 